\title{
Population dynamics of a nonindigenous epiphytic bryozoan Membranipora membranacea in the western North Atlantic: effects of kelp substrate
}

\author{
Megan I. Saunders*, Anna Metaxas \\ Department of Oceanography, Dalhousie University, Halifax, Nova Scotia, B3H 4J1, Canada
}

\begin{abstract}
In rocky subtidal ecosystems of the western North Atlantic, the nonindigenous epiphytic bryozoan Membranipora membranacea facilitates the introduction of other nonindigenous benthic species by defoliating kelps. Susceptibility to infestation by the bryozoan varies among kelp species, although the causes of this variability are not known. We monitored the percent cover of the bryozoan on Saccharina longicruris, Laminaria digitata, and Agarum clathratum, at 2 to 3 depths within 3 sites over 15 mo in 2005 to 2006. To infer mechanisms of observed differences in cover, we examined patterns of colony settlement and abundance, size-frequency distributions, and the proportion of plants with overwintering bryozoans on the respective kelp species. We also quantified the distributions and abundances of kelps before and after a major defoliation event in the fall of 2006. During the peak in abundance in fall, the highest percent cover of the bryozoan was consistently observed on L. digitata, which was achieved by colonies attaining larger sizes. The lowest cover and abundance were observed on A. clathratum, a pattern that we attributed to lower recruitment. Following an outbreak of the bryozoan in the fall of 2006, defoliation of the kelp bed was due to losses of individuals of $S$. longicruris, and to a lesser extent, A. clathratum, but not to losses of L. digitata, which increased in abundance at 1 location. Our results suggest that differences in the abundance of this introduced species among its algal hosts arise as a result of both differential settlement and survival. In turn, differential susceptibility among hosts to infestation may result in alteration of the algal community structure.
\end{abstract}

KEY WORDS: Invasive species - Kelp beds · Rocky subtidal ecosystems · Epibiota · Bryozoa · Membranipora membranacea · Western North Atlantic

\section{INTRODUCTION}

The rocky subtidal ecosystem in the western North Atlantic has historically been dominated by luxuriant kelp beds, which provide food and habitat for a wide variety of organisms. However, in recent decades, a suite of nonindigenous species have invaded the region, causing significant alteration to the benthic community (Berman et al. 1992, Lambert et al. 1992, Scheibling et al. 1999, Harris \& Tyrrell 2001, Levin et al. 2002). In the western North Atlantic, the epiphytic encrusting bryozoan Membranipora membranacea was first observed in the Gulf of Maine in 1987 (Berman et al. 1992), where it was likely introduced from Europe (Schwaninger 1999). It became established in Nova Scotia (Canada), in Mahone Bay and St. Margarets Bay, by 1992 (Scheibling et al. 1999). Taxonomically, M. membranacea is a spatially disjunct and cryptic species complex, and includes populations in both the Pacific and Atlantic, in each of the northern and southern hemispheres (e.g. the western US and Canada, Japan, Australia, New Zealand, Chile, South Africa, and western Europe; Schwaninger 2008). In the introduced range, encrustations of M. membranacea on the blades of laminarian algae (kelps) cause them to become brittle and friable and to break during periods of intense wave action in fall (Berman et al. 1992, Scheibling et al. 1999). Pronounced outbreaks of this 
species in certain years have resulted in mass defoliation of the western Atlantic kelp beds by mid-November (Berman et al. 1992, Lambert et al. 1992, Scheibling et al. 1999, Saunders \& Metaxas 2008, Scheibling \& Gagnon 2009). Due to this alteration of the benthic habitat, $M$. membranacea facilitates the colonization and establishment of other species, such as the introduced algae Codium fragile fragile (Levin et al. 2002, Scheibling \& Gagnon 2006). C. fragile is of lower nutritional quality than kelp (Lyons \& Scheibling 2007), and its presence results in changes in the associated benthic community structure (Schmidt \& Scheibling 2007). Consequently, by facilitating the removal and replacement of kelps, M. membranacea alters the habitat of ecologically and economically important species, such as sea urchins and lobsters (Chapman et al. 2002).

Epibiotic organisms typically occur on one or few particular species, a pattern usually caused by behavioral choices during settlement (Ryland 1959). In the laboratory, larvae of Membranipora membranacea are induced to settle by the presence of kelp (Laminaria saccharina) (Stricker 1989), indicating that a chemical cue for settlement may be released by the algae (Seed \& O'Connor 1981). However, settlement of M. membranacea is not necessarily uniform among kelp species. For example, in Point Loma, California, USA, a difference in the abundances of $M$. membranacea colonies between the understory kelp Pterygophora californica and the canopy kelp Macrocystis pyrifera was attributed to variations in settlement on the $2 \mathrm{kelp}$ species (Bernstein \& Jung 1979). The production of chemical compounds by macroalgae may also defend against recruitment of epiphytic organisms, and the allocation of these chemical defenders varies with species, tissue type, and environmental variables (Van Alstyne et al. 1999). Differences in the abundance of epiphytic organisms among host species could therefore be the result of differences in the strength of chemical cues involved in inducing or deterring settlement.

Kelp blades continuously grow and erode from the basal and distal ends, respectively, with blade tissue turning over between 1 and 5 times a year (Mann 1973), For epiphytic organisms, differences in abundance among substrate species will be influenced by the dynamic nature of kelp blades, and as a consequence, epiphytic organisms must have short life spans, continuous reproduction, and rapid growth to survive on such ephemeral habitats (Bernstein \& Jung 1979). Seasonal cycles of growth and their response to environmental variables differ among kelp species (Schaffelke \& Lüning 1994, Makarov et al. 1999), and vary spatially and temporally within a species (Gerard \& Mann 1979, Makarov et al. 1999). In Nova Scotia, growth of kelp is highest in late winter or early spring, and higher in shallower than deeper water (Mann
1973). Algal species with faster growth and erosion rates could achieve lower coverage of epiphytes because epiphytes are removed concurrently with eroding kelp tissue. Consequently, variations in epiphyte abundance among kelp species could be caused by differential longevity on different hosts.

There are 5 kelp species in Atlantic Canada, all which are epiphytized by Membranipora membranacea in varying degrees (M. Saunders pers. obs.). In St. Margarets Bay, Nova Scotia, 3 kelp species, Saccharina longicruris (formerly Laminaria longicruris, Lane et al. 2006), Laminaria digitata, and Agarum clathratum (also called A. cribrosum; Fig. 1), historically accounted for $80 \%$ of the biomass of macrophytes (Mann 1973). The most ubiquitous, S. longicruris (Fig. 1A), is found in a variety of habitats ranging from sheltered coves to wave-exposed shores. Blades of $S$. longicruris have fluted edges, a morphologically plastic characteristic for which the degree of crenulation depends on water motion (Gerard \& Mann 1979). In shallower and more wave-exposed locations, $S$. longicruris is replaced by L. digitata (Fig. 1B), a species with digitated and strap-like blades that can withstand strong waveinduced forces (Harder et al. 2006). In deeper water, $S$. longicruris is replaced by A. clathratum (Fig. 1C), a species with heavily perforated blades that are thought to be chemically defended against herbivory (Larson et al. 1980). Two other species, Saccorhiza dermatodea and Alaria esculenta, are present, but typically in very low abundance at depths of 4 to $12 \mathrm{~m}$.

In Nova Scotia, population outbreaks of Membranipora membranacea are strongly positively linked to periods of warmer water temperature (Saunders \& Metaxas 2007, 2008, Scheibling \& Gagnon 2009). However, these studies examined aspects of the population dynamics of the bryozoan on only 1 algal species ( $S a c-$ charina longicruris, Saunders \& Metaxas 2007, 2008) or on several algal species combined (Scheibling \& Gagnon 2009). Comparisons of the abundance (percent cover) of $M$. membranacea on various algal species have typically been made non-systematically on one or a few dates, only providing a 'snapshot' in time (e.g. Harris \& Jones 2005). In the introduced range in the western North Atlantic, the growth and abundance of both M. membranacea (Saunders \& Metaxas 2007, 2008, 2009, Scheibling \& Gagnon 2009), and its algal hosts (Gerard \& Mann 1979, Scheibling \& Gagnon 2009) vary both temporally (month to year) and spatially ( $\mathrm{m}$ to $\mathrm{km}$ ), and the examination of the population dynamics of this epiphytic species among algal substrates should encompass these ranges.

The primary objective of this study was to examine effects of algal substrate on the population dynamics of the introduced epiphytic bryozoan Membranipora membranacea, focusing on the 3 dominant kelp species in 
Nova Scotia. To characterize the algal community before and after an outbreak of M. membranacea, we quantified spatial and temporal patterns in the abundances of Saccharina longicruris, Laminaria digitata, and Agarum clathratum in June of 2 years. To examine the effect of algal substrate on the abundance of $M$. mem-
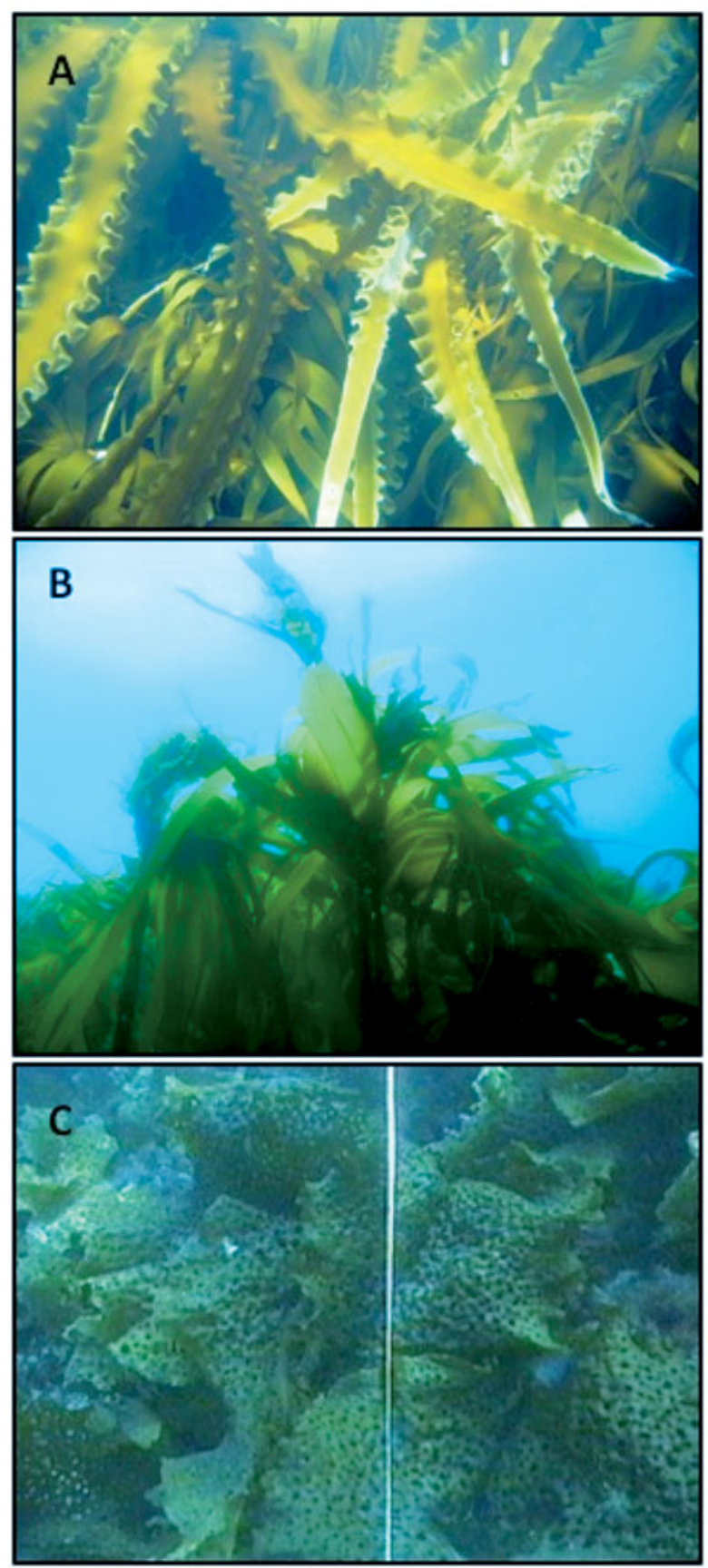

Fig. 1. (A) Saccharina longicruris, (B) Laminaria digitata, and (C) Agarum clathratum. Three kelp species used in this study to examine population dynamics of the encrusting bryozoan Membranipora membranacea on the southern shore of Nova Scotia, Canada. Image in (C) courtesy of A. Pinder, Dalhousie University (white line is a transect used for placing quadrats) branacea, we quantified differences in percent cover, settlement, adult colony abundance, and size-frequency distributions of the bryozoan on each of these species over 2 seasonal cycles. Our results suggest that variations in the susceptibility of kelps to infestation by the nonindigenous bryozoan may result in a shift in the kelp community structure. This could have implications for the stability of rocky subtidal ecosystems, with consequent impacts on populations of commercially important species, such as sea urchins and lobsters.

\section{MATERIALS AND METHODS}

Study area. We sampled at 3 sites on the southern shore of Nova Scotia (Fig. 2), all of which had luxuriant kelp beds and an understory of turf algal species during the early part of the study period. An outbreak of Membranipora membranacea at the end of the study period in fall 2006 resulted in a $70 \%$ reduction of the cover of the Saccharina longicruris canopy on the ben-

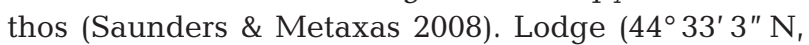
$\left.64^{\circ} 01^{\prime} 9^{\prime \prime} \mathrm{W}\right)$ is located on the western shore of St. Margarets Bay with a moderately steeply sloping substratum dominated by large boulders. Paddy's Head $\left(44^{\circ} 31^{\prime} 6^{\prime \prime} \mathrm{N}, 63^{\circ} 57^{\prime} 2^{\prime \prime} \mathrm{W}\right)$ is located on the eastern shore near the mouth of St. Margarets Bay, and we sampled at the outer wall, where a steeply sloping bedrock substratum gives way to a sandy bottom at $18 \mathrm{~m}$. Sandy Cove ( $\left.44^{\circ} 27^{\prime} 6^{\prime \prime} \mathrm{N}, 63^{\circ} 42^{\prime} 4^{\prime \prime} \mathrm{W}\right)$ is located in Terence Bay, $20 \mathrm{~km}$ to the east of St. Margarets Bay, where the topography from 0 to $11 \mathrm{~m}$ depth consists of bedrock ridges interspersed with sand patches. Paddy's Head and Sandy Cove are moderately exposed to the predominant ocean swells, whereas Lodge is more sheltered. The sites were sampled at permanently marked depths $(4,8$, and $12 \mathrm{~m}$ relative to chart datum at Lodge and Paddy's Head; 4, 8, and 10-11 m at Sandy Cove) along a transect perpendicular to shore. It was logistically difficult to access the deepest location at Sandy Cove; therefore, at that depth the kelp community was characterized initially, but it was not sampled for the bryozoan on subsequent dates. The term 'location' will be hereafter used to refer to specific depth by site combinations (e.g. $4 \mathrm{~m}$ at Sandy Cove, $12 \mathrm{~m}$ at Lodge).

Quantification of the kelp assemblage and proportion of plants with overwintered bryozoan colonies. The abundance of individuals of all established $(>20 \mathrm{~cm}$ ) kelp species was quantified at each location at the beginning of the study period in mid-June 2005. The kelp community was subsequently re-sampled in June 2007 (after the study period) at each depth at Lodge and Paddy's Head, but not at Sandy Cove. At each location, we quantified the number of kelps 


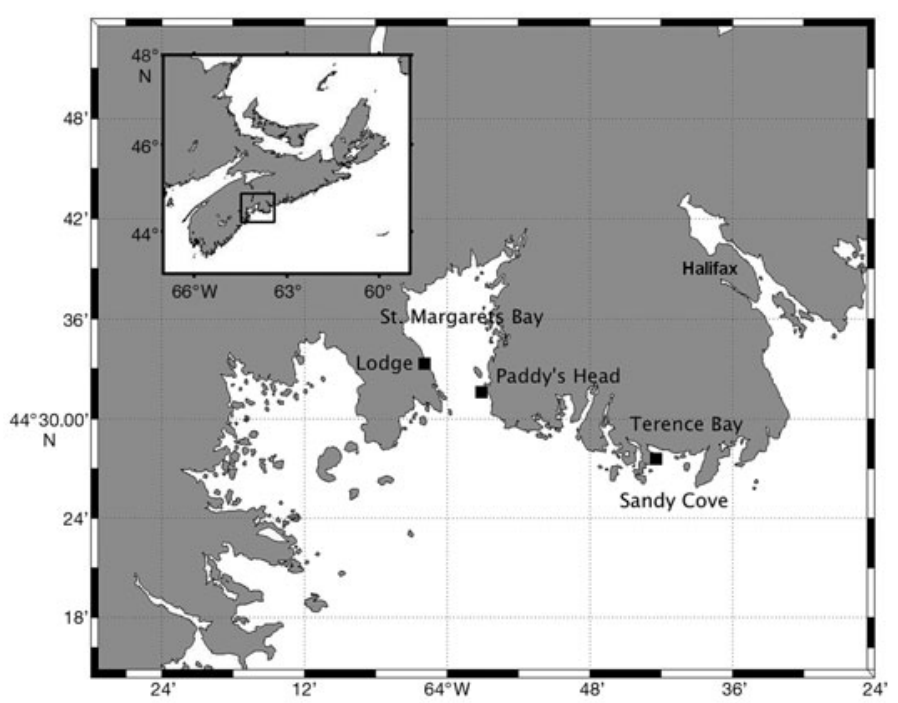

Fig. 2. Study sites on the southern shore of Nova Scotia, Canada

within 11 to 20 randomly placed $0.25 \mathrm{~m}^{2}$ quadrats along $30 \mathrm{~m}$ transects oriented parallel to shore. The starting location of each transect was selected haphazardly, and the locations of the quadrats along each transect were selected using random numbers to determine distance from the start of the transect. In 2007, to avoid the impact of our previous collections (see below) on the measured abundance of kelp, quadrats were enumerated in an area adjacent to the region from which kelps were collected for Membranipora membranacea samples. For each quadrat, the presence or absence of overwintered colonies of $\mathrm{M}$. membranacea on holdfasts, stipes, or blades of each algal species, as well as on holdfasts or stipes with no blades, was also recorded.

Collection of bryozoan colonies on kelp blades. We sampled colonies of Membranipora membranacea on blades of the 3 numerically most abundant species, Saccharina longicruris, Laminaria digitata, and Agarum clathratum (Fig. 1), although not all of these species occurred at all locations (Fig. 3). S. longicruris was present at each location and was sampled the most intensively to characterize spatial and temporal patterns of bryozoan abundance (approximately weekly from 1 July to 4 August 2005, and in September 2005, and approximately monthly from October 2005 through to November 2006; for sampling details and analyses of spatial and temporal patterns, see Saunders \& Metaxas 2007, 2008). Blades of L. digitata and A. clathratum were sampled approximately monthly from July 2005 to June 2006, and in November 2006. On each sampling date, approximately 10 blades (typically around 60 to $150 \mathrm{~cm}$ in length) per species were haphazardly collected from the locations where they were sufficiently abundant. Kelps were transported to Dalhousie University's Aquatron facility in plastic tubs without seawater (time in transit $=3$ to $6 \mathrm{~h}$ ), where they were kept in aquaria with running ambient seawater until processing was completed (1 to $8 \mathrm{~d}$ ).

Percent cover of Membranipora membranacea on kelp. The surface area of $M$. membranacea on each kelp blade was obtained by tracing all the colonies on 1 side of the blade onto clear plexiglass. The tracings were then photographed using an HP Photosmart 435 3.1MP digital camera, and bryozoan area was measured using SPSS ${ }^{\circledR}$ SigmaScan Pro Image Analysis 5.0. Percent cover of $M$. membranacea on kelp was calculated by dividing the surface area of bryozoan cover by the surface area of the kelp blade (measured from photographs as for bryozoan cover) and multiplying by 100. The blades of Saccharina longicruris are extensively crenulated; therefore, their projected surface area in the images was corrected using locationspecific correction factors (Saunders \& Metaxas 2007).

Abundances and size-frequency distributions of bryozoan colonies. Membranipora membranacea colonies were enumerated and measured on a subsample of each kelp blade, using $15 \times$ magnification and LED lighting when necessary. The maximum dimension of each colony was measured using a clear plastic ruler (accuracy $1 \mathrm{~mm}$ ). For colonies $<2 \mathrm{~mm}$, the maximum number of rows of zooids from the ancestrula to the outer edge of the colony was counted and the length of the colony was calculated using a known relationship between the two (Saunders \& Metaxas 2008). New settlers were defined as any colony with fewer than 3 fully formed zooids (i.e. 2 zooid rows, Saunders \& Metaxas 2007; 2 zooid generations, Saunders \& Metaxas 2009). Adult colonies were defined as colonies $>2 \mathrm{~mm}$ (Saunders \& Metaxas 2008). For each algal species, 1 side of each kelp blade was sampled for colonies from July to September 2005. Colonies settle on both sides of the kelp blade, and there is no distinct difference in the number of colonies between sides (M. Saunders unpubl. data). When colony abundance increased markedly in September 2005 and for the remainder of the study period (except for September 2006), 1 randomly chosen half (longitudinally sectioned) of 1 side of each kelp blade was sampled. During the peak in settlement in September 2006, colonies on S. longicruris and L. digitata were sub-sampled within 12 square sections $\left(25 \mathrm{~cm}^{2}\right)$ of each blade haphazardly selected from the edge and from the center of the blade. Colonies were enumerated if $>50 \%$ was within the sampled area, leading to an underestimation of the abundance of larger (>20 mm) colonies for September 2006. Colonies $<2 \mathrm{~mm}$ were not enumerated on Agarum clathratum on any date due to difficulty in locating such small colonies on the extensively perforated blades. 


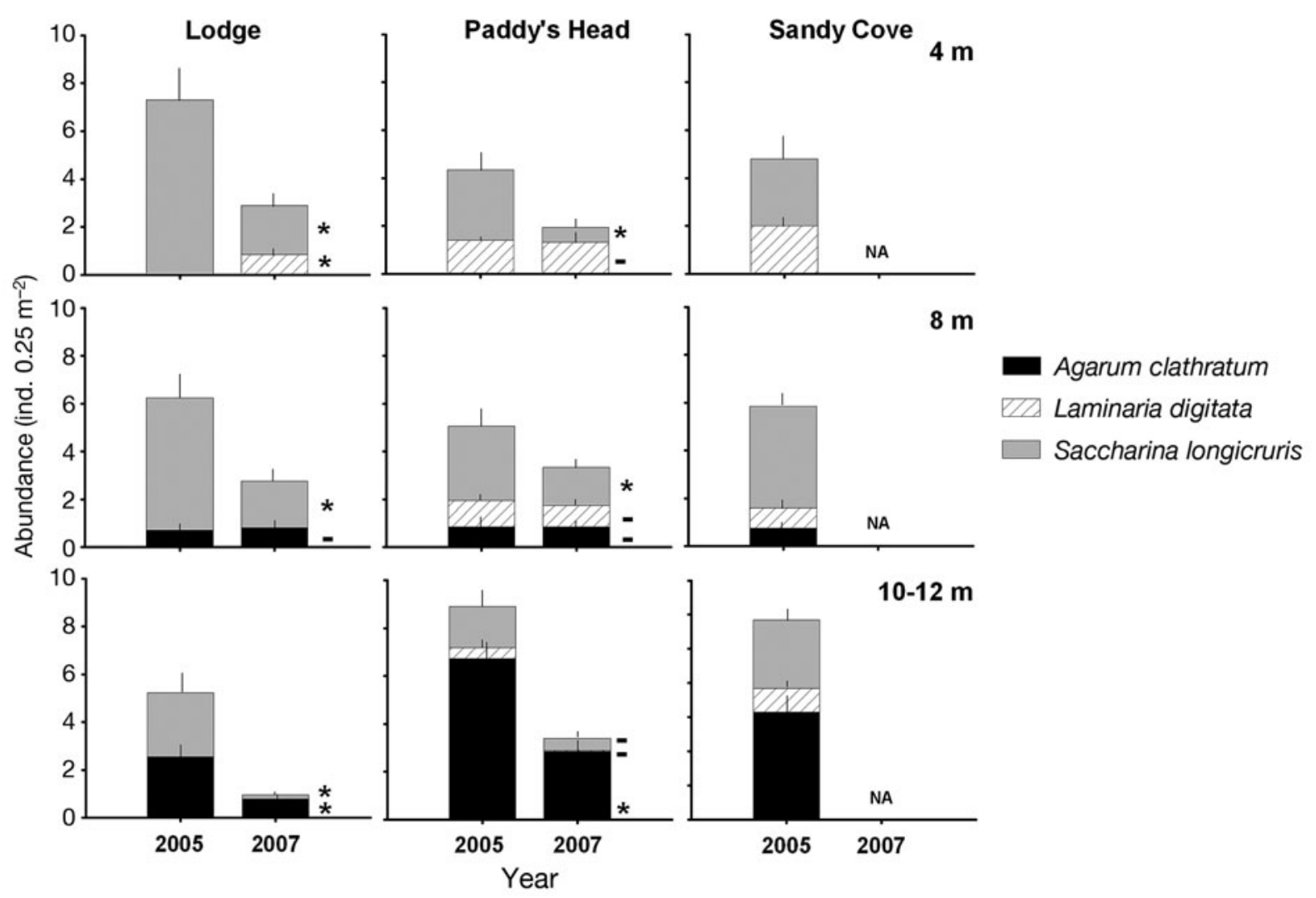

Fig. 3. Agarum clathratum, Laminaria digitata, and Saccharina longicruris. Abundance (individual plants $0.25 \mathrm{~m}^{-2}$ benthos, mean $+\mathrm{SE}$ ) of 3 kelp species at 3 depths at 3 sites on the southern shore of Nova Scotia, Canada, in mid-June of 2 years. An outbreak of Membranipora membranacea occurred at these sites in fall 2006. *(-): significant (non-significant) differences in the abundance of particular kelp species (analyses conducted for $A$. clathratum and L. digitata) between years using $t$-tests. Results for Saccharina longicruris shown in Saunders \& Metaxas (2008)

Statistical analyses. At each location, the effect of year on the abundance (plants $0.25 \mathrm{~m}^{-2}$ benthos) of each of Laminaria digitata and Agarum clathratum was examined using Student's $t$-test, assuming unequal variances. If either species was present at a particular location in only 1 year, a 1-sample $t$-test was used to compare the abundance in that year to 0. Similar analyses for the abundance of Saccharina longicruris can be found in Saunders \& Metaxas (2008).

The effect of year $(2005,2007)$ on the percentage of plants with overwintered bryozoans (percent occurrence) was examined using 1-way analysis of covariance (ANCOVA), with depth $(4,8,12 \mathrm{~m})$ as the covariate. Each data point represented the percentage of plants (Saccharina longicruris, Laminaria digitata, Agarum clathratum, and stipes with no blades) at a location with overwintered colonies. Because there was a significant interaction term between the covariate and the main factor, the relationship between the occurrence of overwintered colonies and depth was examined independently for each year using simple linear regression.
Analyses on measures of population abundance were done for the seasonal peak of the bryozoan population in each year, which, unless otherwise noted (Table 1), occurred in November. In 2005, the bryozoan population was sampled at high temporal resolution, and the dates selected for the analyses captured the seasonal peak of M. membranacea. In 2006, data for November fell within the period of decline following an earlier seasonal peak in September or October (Saunders \& Metaxas 2007, 2008). The effect of substrate species (fixed factor: Saccharina longicruris, and Laminaria digitata and/or Agarum clathratum, depending on location) on each of percent cover, abundance of settlers, and abundance of adult colonies was examined for each location (details given in Table 1), with Student's $t$-test or 1-way analysis of variance (ANOVA; depending on whether 2 or 3 algal species were present). No analysis was done for $4 \mathrm{~m}$ at Lodge because only $S$. longicruris was sampled at that location. Analyses for the abundance of settlers were only conducted for 4 and $8 \mathrm{~m}$ at Paddy's Head and Sandy Cove because those were the only locations where settlers were enumerated on more than 1 species of kelp. 
Table 1. Membranipora membranacea. Results of the statistical analyses of the effects of algal substrate species on the abundance of $M$. membranacea (percent cover, newly settled colonies $\mathrm{m}^{-2}$ kelp, adult colonies $\mathrm{m}^{-2}$ kelp). Significant effects at $\alpha=0.01$ are indicated in bold. Percent cover and density data were arcsine-square root $(x)$ - and $\log (x+1)$-transformed, respectively, to satisfy the assumption of homogeneity of variances as detected by Levene's tests. PH: Paddy's Head; SC: Sandy Cove; LO: Lodge, S: Saccharina longicruris;

L: Laminaria digitata; A: Agarum clathratum. Dates are shown as d/mo/yr

\begin{tabular}{|c|c|c|c|c|c|c|c|}
\hline Variable & Location & Date & Species & $t$ or $F$ & $\mathrm{df}$ & $\mathrm{p}$ & Differences \\
\hline \multirow[t]{14}{*}{ Cover $(\%)$} & \multirow[t]{2}{*}{$\mathrm{PH}, 4 \mathrm{~m}$} & $29 / 11 / 05$ & $\mathrm{~S}, \mathrm{~L}$ & -1.96 & 10 & $0.079^{a}$ & \\
\hline & & $13 / 11 / 06$ & $\mathrm{~S}, \mathrm{~L}$ & -1.78 & 14 & 0.097 & \\
\hline & \multirow[t]{2}{*}{$\mathrm{SC}, 4 \mathrm{~m}$} & 09/12/05 & $\mathrm{S}, \mathrm{L}$ & -4.13 & 17 & 0.001 & $\mathrm{~S}<\mathrm{L}$ \\
\hline & & $19 / 11 / 06$ & $\mathrm{~S}, \mathrm{~L}$ & -4.72 & 18 & $<0.001$ & $\mathrm{~S}<\mathrm{L}$ \\
\hline & \multirow[t]{2}{*}{$\mathrm{PH}, 8 \mathrm{~m}$} & $29 / 11 / 05$ & $\mathrm{~S}, \mathrm{~L}, \mathrm{~A}$ & 22.7 & 2,26 & $<0.001$ & $\mathrm{~S}=\mathrm{A}<\mathrm{L}$ \\
\hline & & $13 / 11 / 06$ & $\mathrm{~S}, \mathrm{~L}, \mathrm{~A}$ & 3.04 & 2,23 & 0.067 & \\
\hline & \multirow[t]{2}{*}{$\mathrm{SC}, 8 \mathrm{~m}$} & $29 / 10 / 05$ & $\mathrm{~S}, \mathrm{~L}, \mathrm{~A}$ & 13.8 & 2,22 & $<0^{001}{ }^{\mathrm{a}}$ & $\mathrm{S}=\mathrm{A}<\mathrm{L}$ \\
\hline & & $19 / 11 / 06$ & $\mathrm{~S}, \mathrm{~L}$ & -3.08 & 17 & 0.007 & $\mathrm{~S}<\mathrm{L}$ \\
\hline & \multirow[t]{2}{*}{$\mathrm{LO}, 8 \mathrm{~m}$} & $29 / 11 / 05$ & $\mathrm{~S}, \mathrm{~A}$ & 1.40 & 16 & 0.18 & \\
\hline & & $19 / 11 / 06$ & $\mathrm{~S}, \mathrm{~A}$ & 2.63 & 18 & 0.017 & \\
\hline & \multirow[t]{2}{*}{$\mathrm{PH}, 12 \mathrm{~m}$} & $29 / 11 / 05$ & $\mathrm{~S}, \mathrm{~A}$ & 4.46 & 18 & $0.001^{\mathrm{a}}$ & $\mathrm{S}>\mathrm{A}$ \\
\hline & & $13 / 11 / 06$ & $\mathrm{~S}, \mathrm{~A}$ & 2.44 & 13 & $0.03^{\mathrm{a}}$ & \\
\hline & \multirow[t]{2}{*}{$\mathrm{LO}, 12 \mathrm{~m}$} & $29 / 11 / 05$ & $\mathrm{~S}, \mathrm{~A}$ & 5.21 & 9 & $0^{001} 1^{a}$ & $\mathrm{~S}>\mathrm{A}$ \\
\hline & & 19/11/06 & $\mathrm{S}, \mathrm{A}$ & 7.18 & 17 & $<0.001$ & $\mathrm{~S}>\mathrm{A}$ \\
\hline \multirow[t]{9}{*}{ Settlers } & \multirow[t]{3}{*}{$\mathrm{PH}, 4 \mathrm{~m}$} & $19 / 10 / 05$ & $\mathrm{~S}, \mathrm{~L}$ & 1.50 & 13 & 0.157 & \\
\hline & & $29 / 11 / 05$ & $\mathrm{~S}, \mathrm{~L}$ & -2.12 & 17 & 0.049 & \\
\hline & & $13 / 11 / 06$ & $\mathrm{~S}, \mathrm{~L}$ & -0.23 & 14 & 0.823 & \\
\hline & \multirow[t]{2}{*}{$\mathrm{SC}, 4 \mathrm{~m}$} & 09/12/05 & $\mathrm{S}, \mathrm{L}$ & 1.25 & 17 & 0.227 & \\
\hline & & $19 / 11 / 06$ & $\mathrm{~S}, \mathrm{~L}$ & -0.17 & 18 & 0.869 & \\
\hline & \multirow[t]{2}{*}{$\mathrm{PH}, 8 \mathrm{~m}$} & $19 / 10 / 05$ & $\mathrm{~S}, \mathrm{~L}$ & 2.23 & 13 & 0.044 & \\
\hline & & $13 / 11 / 06$ & $\mathrm{~S}, \mathrm{~L}$ & -2.42 & 14 & 0.03 & \\
\hline & \multirow[t]{2}{*}{$\mathrm{SC}, 8 \mathrm{~m}$} & $29 / 10 / 05$ & $\mathrm{~S}, \mathrm{~L}$ & -0.78 & 16 & 0.45 & \\
\hline & & 19/11/06 & $\mathrm{S}, \mathrm{L}$ & -0.30 & 17 & 0.77 & \\
\hline \multirow[t]{11}{*}{ Adults } & \multirow[t]{2}{*}{$\mathrm{PH}, 4 \mathrm{~m}$} & $29 / 11 / 05$ & $\mathrm{~S}, \mathrm{~L}$ & 1.63 & 17 & 0.122 & \\
\hline & & $13 / 11 / 06$ & $\mathrm{~S}, \mathrm{~L}$ & -2.50 & 14 & $0.026^{\mathrm{a}}$ & \\
\hline & \multirow[t]{2}{*}{$\mathrm{SC}, 4 \mathrm{~m}$} & 09/12/05 & $\mathrm{S}, \mathrm{L}$ & 1.30 & 17 & 0.211 & \\
\hline & & $19 / 11 / 06$ & $\mathrm{~S}, \mathrm{~L}$ & -8.70 & 11 & $<0.001^{\mathrm{a}}$ & $\mathrm{S}<\mathrm{L}$ \\
\hline & \multirow[t]{2}{*}{$\mathrm{PH}, 8 \mathrm{~m}$} & 29/11/05 & $\mathrm{S}, \mathrm{L}, \mathrm{A}$ & 4.87 & 2,26 & 0.016 & \\
\hline & & $13 / 11 / 06$ & $\mathrm{~S}, \mathrm{~L}$ & -3.39 & 17 & 0.004 & $\mathrm{~S}<\mathrm{L}$ \\
\hline & \multirow[t]{2}{*}{$\mathrm{SC}, 8 \mathrm{~m}$} & $29 / 10 / 05$ & $\mathrm{~S}, \mathrm{~L}, \mathrm{~A}$ & 27.8 & 2,22 & $<0.001$ & $\mathrm{~S}=\mathrm{L}>\mathrm{A}$ \\
\hline & & $19 / 11 / 06$ & $\mathrm{~S}, \mathrm{~L}$ & -7.99 & 10 & $<0.001^{\mathrm{a}}$ & $\mathrm{S}<\mathrm{L}$ \\
\hline & $\mathrm{LO}, 8 \mathrm{~m}$ & $19 / 10 / 05$ & $\mathrm{~S}, \mathrm{~A}$ & 4.83 & 17 & $<0.001$ & $\mathrm{~S}>\mathrm{A}$ \\
\hline & $\mathrm{PH}, 12 \mathrm{~m}$ & $29 / 11 / 05$ & $\mathrm{~S}, \mathrm{~A}$ & 5.03 & 18 & $<0.001$ & $\mathrm{~S}>\mathrm{A}$ \\
\hline & $\mathrm{LO}, 12 \mathrm{~m}$ & $29 / 11 / 05$ & $\mathrm{~S}, \mathrm{~A}$ & 13.48 & 14 & $<0.001^{\mathrm{a}}$ & $\mathrm{S}>\mathrm{A}$ \\
\hline
\end{tabular}

divided by the total number of colonies $>10 \mathrm{~mm}$. Colonies $<10 \mathrm{~mm}$ were excluded from the calculations to permit comparisons between A. clathratum and the other species.

Percent occurrence of overwintered colonies of bryozoans and percent cover of bryozoans on kelp data were arcsine-square root transformed to remove heterogeneity of variances. Abundances of kelps, newly settled colonies, and adult colonies were $\log (x+1)$ transformed to satisfy the assumption of homogeneity of variances, as detected by Levene's test. In instances when homogeneity of variances could not be achieved through transformations and when only 2 levels were being compared, $t$-tests assuming unequal variances were used. Bryozoan percent cover data at $8 \mathrm{~m}$ at Sandy Cove on 29 October 2005 did not meet the assumption of homogeneity of variances (however, $\alpha \ll \alpha_{\text {criti }}$ therefore the probability of a type I error was small). Analyses were conducted using SPSS 15.0. Where appropriate, homogeneous subsets were identified using Tukey's tests.

\section{RESULTS}

\section{Algal assemblage}

Saccharina longicruris was very abundant at all sites. Laminaria digitata was more abundant at Sandy Cove and Paddy's Head than at Lodge, and its abundance decreased with depth. Agarum clathratum was abundant at $12 \mathrm{~m}$ at all sites, less abundant at $8 \mathrm{~m}$,

Because of the large number of tests performed (34, Table 1), a conservative $\alpha_{\text {crit }}$ of 0.01 was used for these analyses.

Size-frequency distributions at $8 \mathrm{~m}$ (pooled across sites) were generated for colonies on each algal species for late fall 2005 (29 November for Paddy's Head and Lodge, 9 December for Sandy Cove; all 3 species were sampled at that depth at that time). The percentage of colonies in the smallest size category ( 0 to $10 \mathrm{~mm}$ ) was only calculated for Saccharina longicruris and Laminaria digitata since colonies $<2 \mathrm{~mm}$ were not sampled on Agarum clathratum. To explore differences in the abundance of the largest colonies on each kelp species, the number of colonies $>200 \mathrm{~mm}$ was and absent at $4 \mathrm{~m}$ (Fig. 3). The abundance of $A$. clathratum was lower in 2007 than in 2005 at $12 \mathrm{~m}$ at both sites (Lodge: $t_{30.7}=2.8, p=0.008$; Paddy's Head: $\left.t_{5.0}=28.7, \mathrm{p}<0.001\right)$, but did not differ between years at $8 \mathrm{~m}$ at either site (Lodge: $t_{38.9}=-0.25, \mathrm{p}=0.80$; Paddy's Head: $\left.t_{35.5}=-0.20, p=0.85\right)$. Abundance of L. digitata was higher in 2007 than in 2005 at $4 \mathrm{~m}$ at Lodge $\left(t_{17}=4, \mathrm{p}=0.001\right)$, and did not differ between years at Paddy's Head at any depth $\left(4 \mathrm{~m}: t_{23.6}=1.0, \mathrm{p}=\right.$ $\left.0.32 ; 8 \mathrm{~m}: t_{36.3}=0.53, \mathrm{p}=0.60 ; 12 \mathrm{~m}: t_{11.2}=1.5, \mathrm{p}=0.16\right)$. Abundance of $S$. longicruris was lower in 2007 than in 2005 at all depths at Lodge and Paddy's Head, except for $12 \mathrm{~m}$ depth at Paddy's Head (Saunders \& Metaxas 2008). 


\section{Percent cover of bryozoan on kelp}

The seasonal patterns of percent cover of colonies of Membranipora membranacea were similar among kelp species; in general, percent cover of colonies increased in August and peaked between September and November, and decreased through the winter (Fig. 4). However, there were differences in percent cover among substrate species that were consistent among locations (Table 1, Fig. 4). In fall of both 2005 and 2006, at locations where differences in the percent cover of $M$. membranacea on kelp occurred, it was typically highest on Laminaria digitata (when present), intermediate on Saccharina longicruris, and lowest on Agarum clathratum (Fig. 4). Percent cover of the bry- ozoan remained high for a longer duration in the winter on L. digitata than on the other species (Fig. 4).

\section{Abundance of newly settled and adult colonies}

Throughout the sampling period, settlement of Membranipora membranacea did not differ between Saccharina longicruris and Laminaria digitata (Table 1, Fig. 5). During the peak of colony abundance in fall 2005, the abundance of adult colonies was not different between $S$. longicruris and $L$. digitata for any location (Table 1, Fig. 6). However, in fall 2006, abundance of adult colonies was higher on $L$. digitata than on $S$. longicruris at 3 out of 4 locations. In fall 2005, the abun-
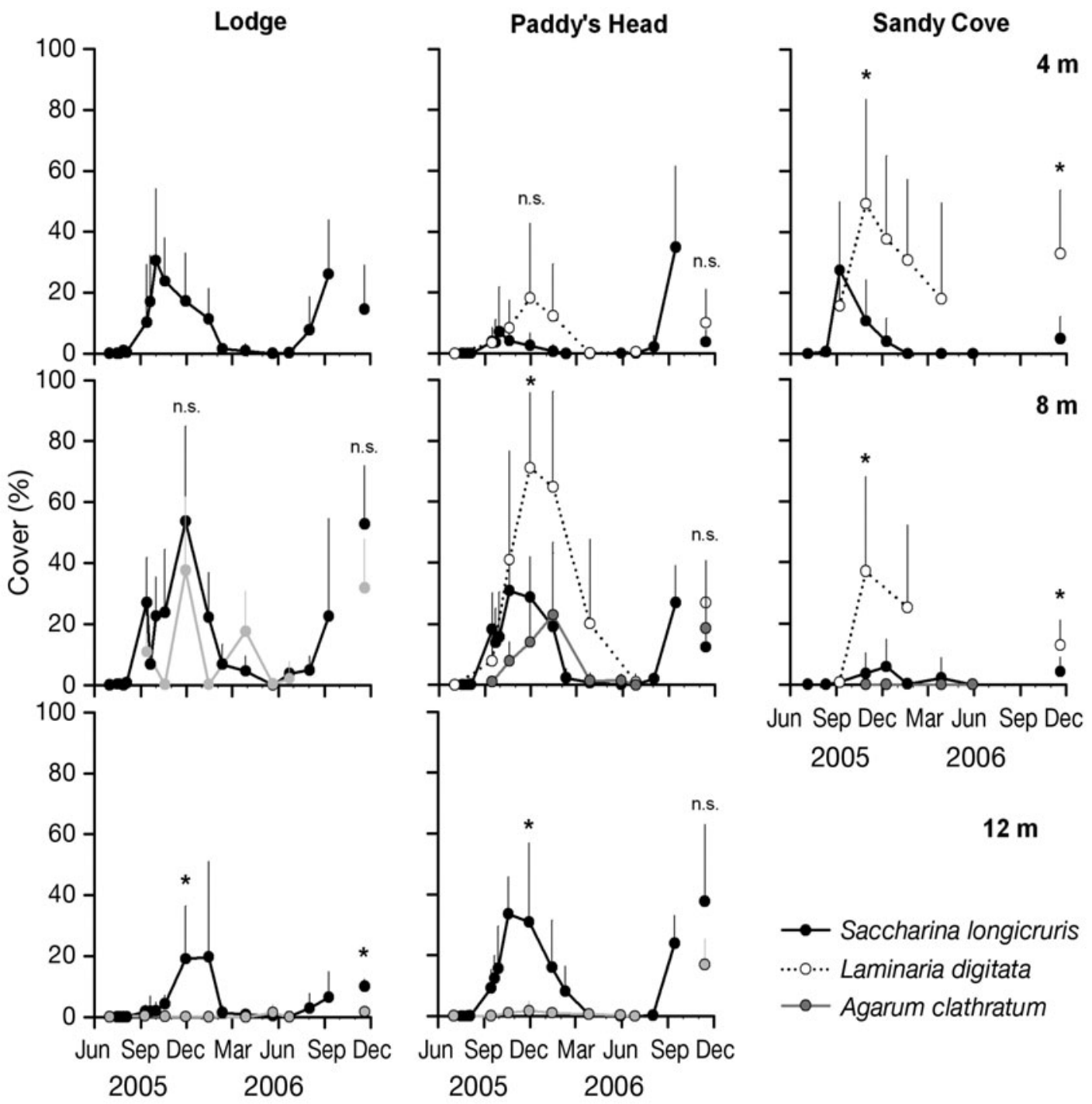

Fig. 4. Membranipora membranacea. Percent cover (mean + SD) of colonies on 3 kelp species sampled at each of 2 to 3 depths and each of 3 sites on the southern shore of Nova Scotia, Canada, from July 2005 to November 2006. ${ }^{*}$ and n.s. indicate dates at the peak of abundance in fall for which 1-way ANOVA or Student's $t$-tests were used to explore differences in percent cover among algal species (n given in Table $1 ;{ }^{*} \mathrm{p}<0.01$; n.s., $\mathrm{p}>0.01$ ) 

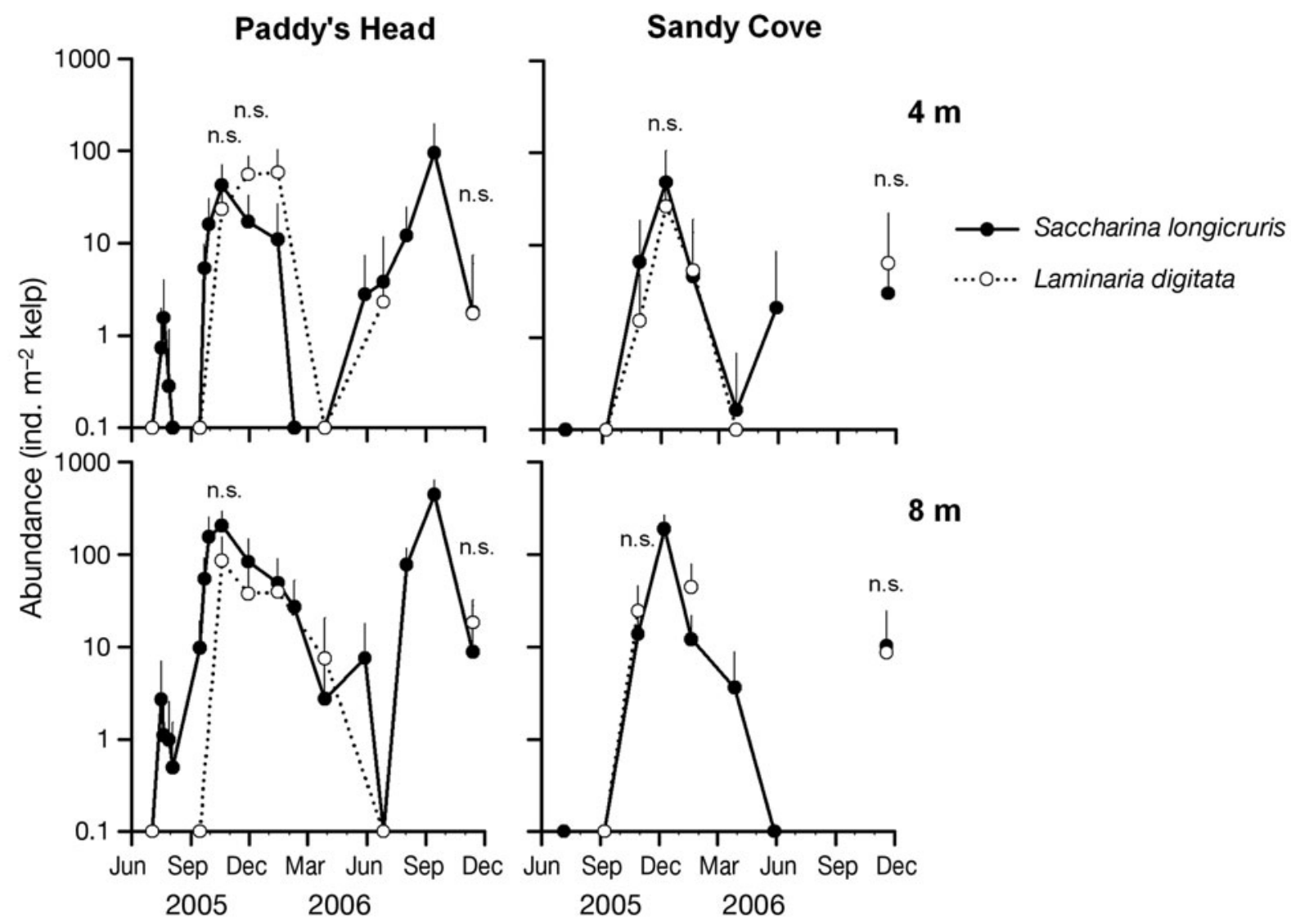

Fig. 5. Membranipora membranacea. Abundance (mean $+\mathrm{SD}$ ) of newly settled colonies on kelp blades (ind. $\left.\mathrm{m}^{-2} \mathrm{kelp}\right)$ on $2 \mathrm{kelp}$ species sampled at each of 2 depths and each of 2 sites on the southern shore of Nova Scotia, Canada, from July 2005 to November 2006. n.s.: non-significant differences among species for dates during the seasonal peak in abundance in fall detected using Student's $t$-tests

dance of adult colonies was lower on Agarum clathratum than on $S$. longicruris at every location except $8 \mathrm{~m}$ at Paddy's Head (Table 1, Fig. 6).

\section{Size-frequency distributions of the bryozoan colonies}

In late fall 2005 (as well as for other dates, data not shown), the size distribution of colonies of Membranipora membranacea was positively skewed on each algal substrate species (Fig. 7). For Laminaria digitata and Saccharina longicruris, 73 and $84 \%$ of colonies were in the 1 to $10 \mathrm{~mm}$ size class, respectively. The maximum size of colonies was largest on L. digitata (473 $\mathrm{mm}$ in November 2005, up to $810 \mathrm{~mm}$ on other dates) and smallest on Agarum clathratum (300 mm in November 2005, up to 415 on other dates), and there were pronounced differences in the relative abundances of larger colonies among algal species (Fig. 7, and M. Saunders unpubl. data). For example, colonies $>200 \mathrm{~mm}$ comprised $38 \%$ of those $>10 \mathrm{~mm}$ on L. digitata (and $10 \%$ of colonies of all sizes), while they com- prised only 3 and $7 \%$ of those $>10 \mathrm{~mm}$ on $S$. longicruris and A. clathratum, respectively.

\section{Overwintering of bryozoan colonies}

Colonies of Membranipora membranacea overwintered on all substrates (Saccharina longicruris, Laminaria digitata, Agarum clathratum, and stipes without blades), but occurrence varied among species both spatially and temporally (Fig. 8). There was a significant interaction between year and depth on the percentage of plants with overwintered colonies (ANCOVA, Year $\times$ Depth: $\left.\mathrm{MS}=0.66, F_{1,46}=8.84, \mathrm{p}=0.005\right)$. The percent occurrence of plants with overwintered colonies of $M$. membranacea increased with depth in 2007 ([arcsinesquare root $y]=-0.195+0.095 x ;$ adjusted $R^{2}=0.40, p=$ 0.002), but not in 2005 (adjusted $R^{2}=0.063, p=0.092$; Fig. 8A). In 2007, at $8 \mathrm{~m}$ at Paddy's Head, percent occurrence of $M$. membranacea was $\sim 8$ times higher on $L$. digitata and $\sim 3$ times higher on $A$. clathratum and stipes with no blades than on $S$. longicruris (Fig. 8B). 


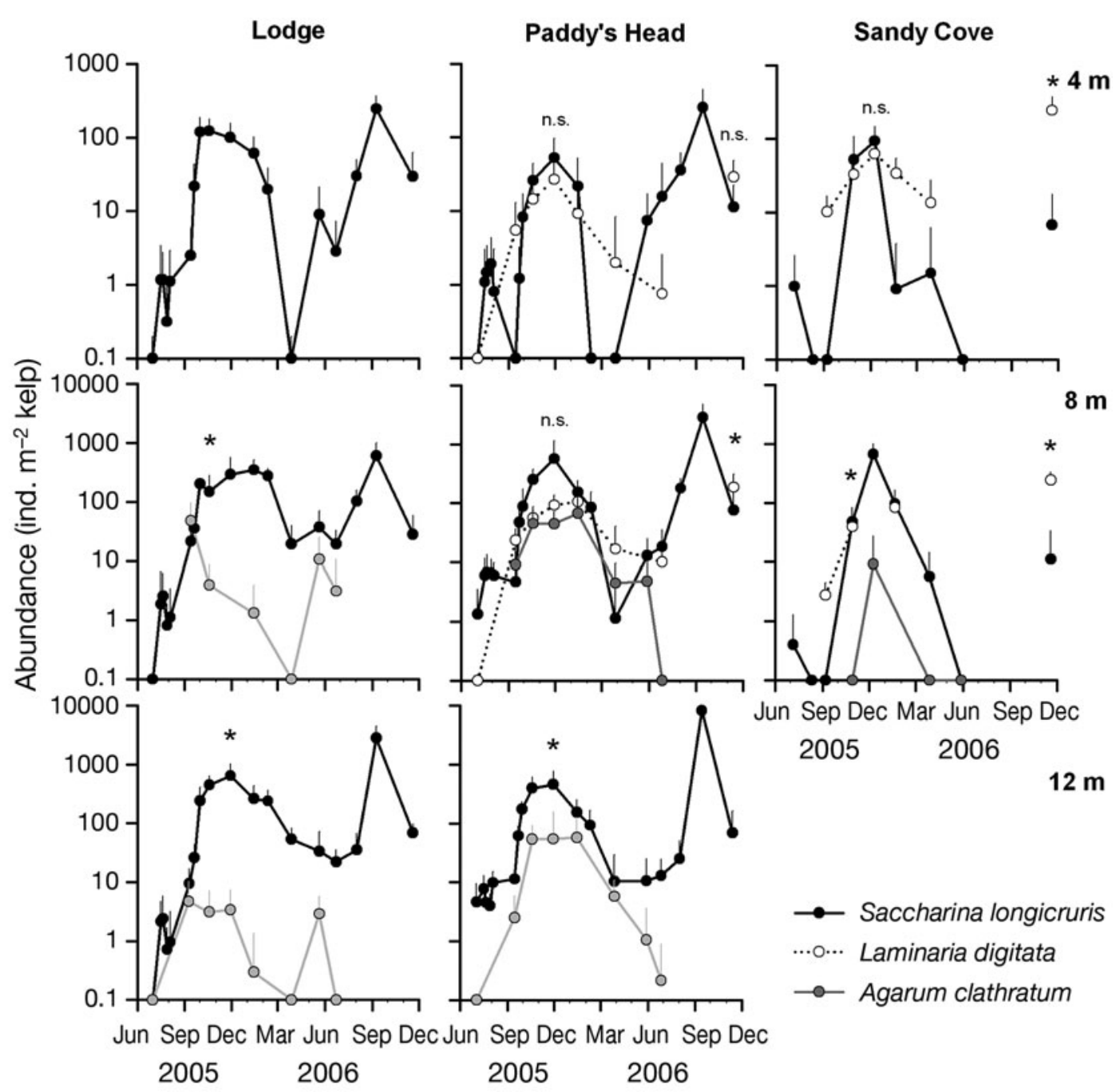

Fig. 6. Membranipora membranacea. Abundance of adult ( $>2 \mathrm{~mm}$ ) colonies (ind. $\mathrm{m}^{-2}$ kelp blade, mean $+\mathrm{SD}$ ) sampled on $3 \mathrm{kelp}$ species at each of 2 to 3 depths at each of 3 sites on the southern shore of Nova Scotia, Canada, from July 2005 to November 2006. * and n.s. indicate dates at the peak of abundance in fall for which 1-way ANOVA or Student's $t$-tests were used to explore differences in percent cover among algal species (n given in Table $1 ;{ }^{*} p<0.01 ;$ n.s.: $p>0.01$ )

\section{DISCUSSION}

There were consistent spatial and temporal patterns in the percent cover of the nonindigenous bryozoan Membranipora membranacea among 3 kelp species at the 3 study sites on the southern shore of Nova Scotia. Coverage of the bryozoan on kelp was generally $\sim 0 \%$ in late spring, began to increase noticeably in August/ September, peaked in October to December, and declined through the winter. At the seasonal peak in November, coverage of $M$. membranacea on each kelp species was not higher in 2006 than in 2005. However, higher coverage in 2006 in August and September compared to 2005 and significant defoliation between October and November 2006 suggest that a peak in cover was missed between sampling intervals in
September and November 2006 (Saunders \& Metaxas 2008). Coverage was typically highest on Laminaria digitata, intermediate on Saccharina longicruris, and lowest on Agarum clathratum, although there was some location- and time-dependent variation in this pattern. Such differences in cover of colonial organisms may arise from differences in settlement and recruitment, growth, partial mortality (senescence or breakage), or complete colony mortality.

In fall, the bryozoan cover was consistently higher on Laminaria digitata than on the other species, and remained high for a longer duration through the winter. The high cover on L. digitata was the result of larger colonies rather than higher rates of settlement. Larger colonies could be obtained either by faster rates of colony growth or by reduced rates of partial colony 

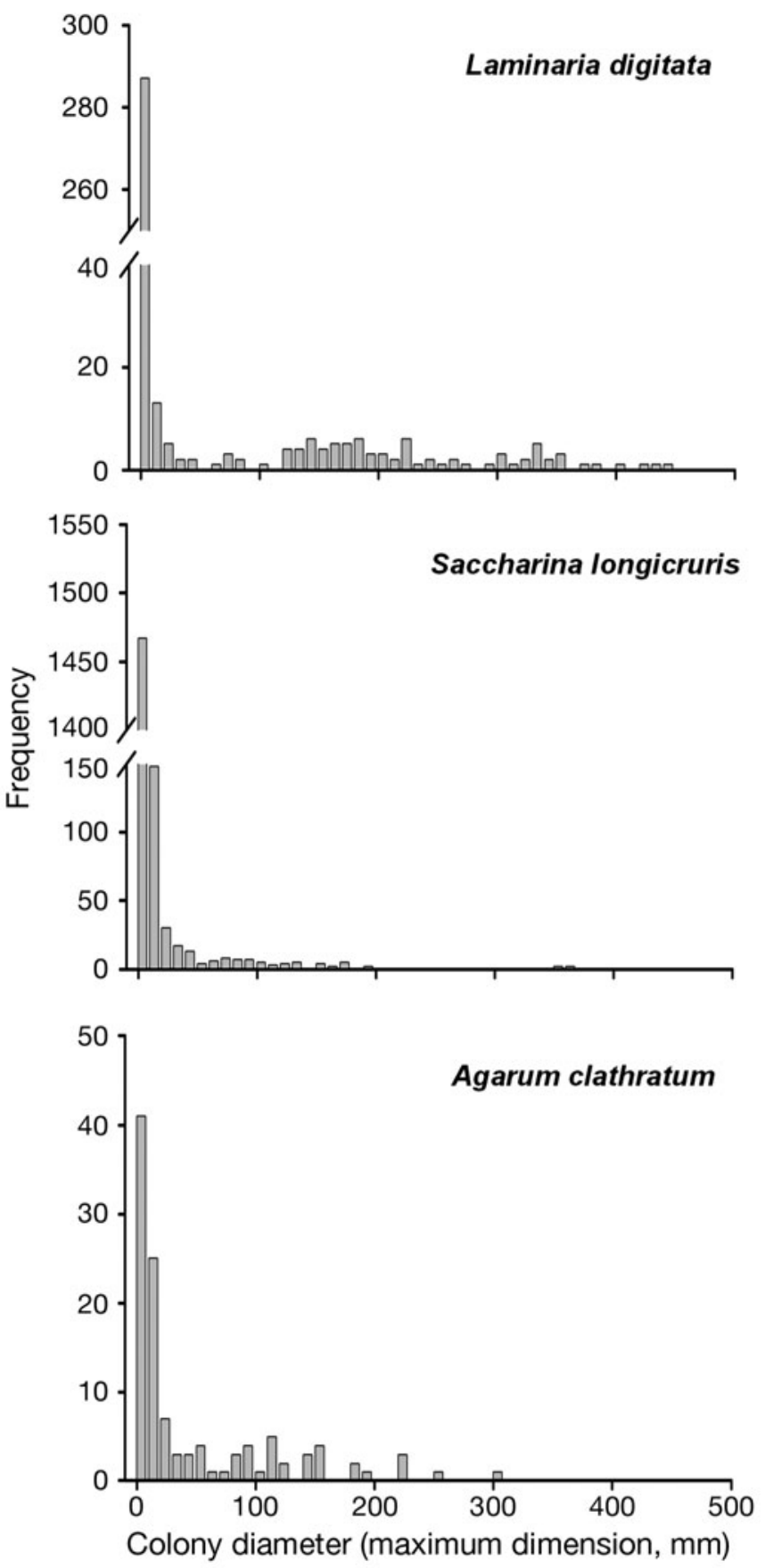

Fig. 7. Membranipora membranacea. Size (maximum dimension, $\mathrm{mm}$ ) frequency distributions of colonies quantified on blades of 3 kelp species sampled at $8 \mathrm{~m}$ depth at 3 sites (pooled) on the southern shore of Nova Scotia, Canada, in late fall 2005 (Lodge and Paddy's Head: 29 November; Sandy Cove: 9 December). N: 394 (Laminaria digitata), 1747 (Saccharina longicruris), and 115 (Agarum clathratum)

loss. We propose that the larger colony sizes on $L$. digitata are a result of reduced rates of fragmentation and breakage of the host alga. A number of observations support this hypothesis. First, the number of adult colonies was not higher on L. digitata than on Saccharina longicruris in fall 2005, but it was higher on $L$. digitata than on $S$. longicruris at 3 out of 4 locations (Table 1) following a major defoliation event (Saunders \& Metaxas 2008) in November 2006. Second, there was a much higher percentage of colonies $>200 \mathrm{~mm}$ on $L$. digitata ( $38 \%$ of those $>10 \mathrm{~mm}$ ) than on the other species ( 3 to $7 \%$ of those $>10 \mathrm{~mm}$ ), suggesting higher survival of large colonies on the former (in our observations, growth was not greater on $L$. digitata than on $S$. longicruris). Third, within a location, the occurrence of overwintering colonies was much higher on L. digitata than on other substrates following the outbreak in fall 2006, suggesting that $L$. digitata plants infested by bryozoans were less likely to be lost by breakage than those of other species. The horizontal and bathymetric distributions of the 3 kelp species suggest that differences in susceptibility to breakage exist among species. L. digitata is found in shallower and more waveexposed locations, whereas Agarum clathratum is found in deeper water where wave action is less energetic. In combination, these observations suggest that higher cover of $M$. membranacea on L. digitata is a result of reduced fragmentation of the underlying kelp tissue of this species. However, comparisons among species of the rates of growth and elongation of blades, the forces necessary to break blades (with and without bryozoan cover), and of variable mortality of bryozoan colonies are clearly necessary.

In this study, a combination of few colonies that were of small sizes resulted in percent cover of the bryozoan that was typically lower on Agarum clathratum than on the other kelp species. Similarly low cover on $A$. clathratum was documented in the Gulf of Maine early in the invasion history of Membranipora membranacea (Berman et al. 1992), and on A. fimbriatum in the eastern North Pacific (Hurd et al. 1994). Among macroalgae, antifouling defenses include the production of chemical compounds that prevent settlement, and sloughing of the epidermis to remove epibionts (Nylund \& Pavia 2005, Wahl 2009). Agarum spp. are thought to be chemically defended against herbivory (Larson et al. 1980), and it is possible that a similar mechanism deters settlement of epiphytic organisms. Polyphenols in the basal meristem of kelps deter damage by grazers (Johnson \& Mann 1986), and are thought to also deter settlement by epibiota (Ragan \& Glombitza 1986). However, the role of these compounds in deterring settlement is contested, since, for example, the phlorotannin content of tissues at different parts of the blade of the kelp Eklonia radiata was only weakly related to the abundance of epiphytic organisms (Jennings \& Steinberg 1997). It is also possible that the perforated morphology of blades of $A$. clathratum is a physical deterrent to settlement, since 

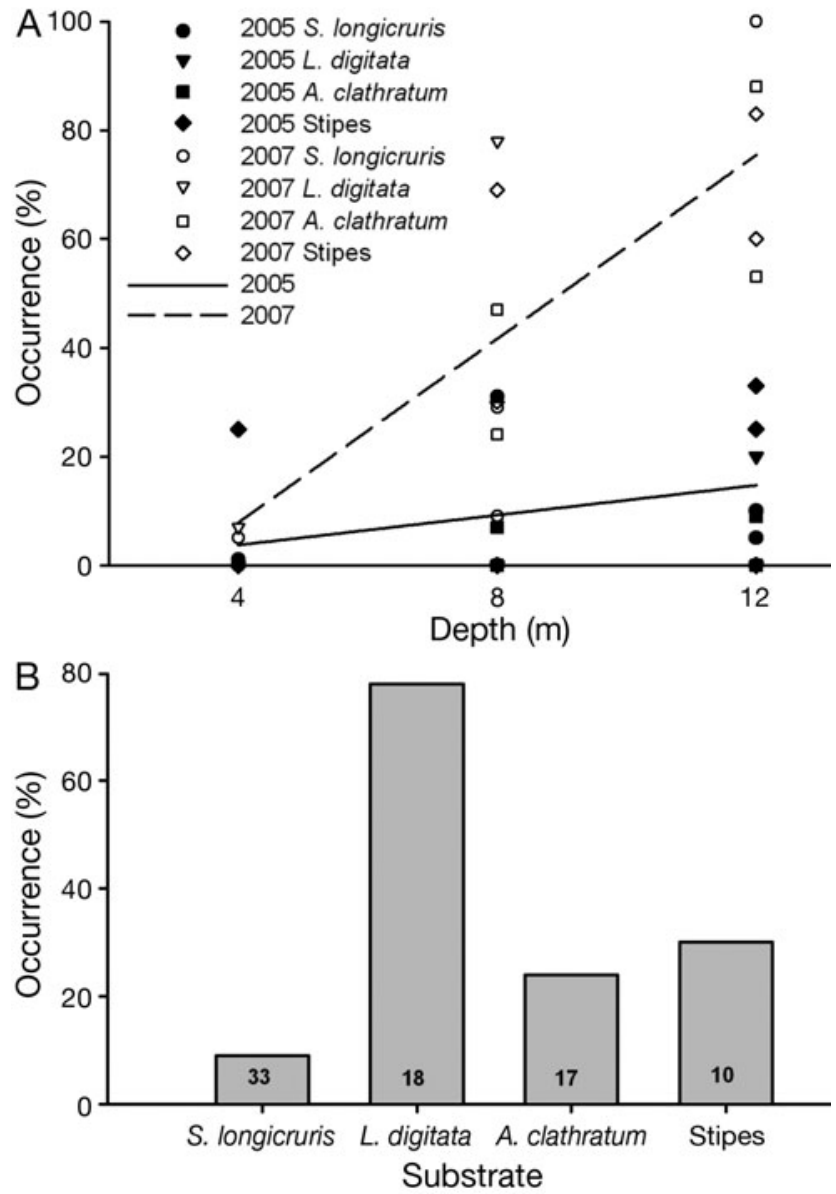

Fig. 8. Agarum clathratum, Laminaria digitata, and Saccharina longicruris. Percentage of kelps with overwintered colonies of Membranipora membranacea: (A) at 3 depths in 2 years on holdfasts, stipes, or blades of 4 different algal substrates (pooled across sites), and (B) at a single location in 1 year (8 m depth at Paddy's Head in 2007). N (kelps sampled) indicated on bars. 'Stipes' were individuals of either $S$. longicruris or L. digitata that did not have a blade, and thus could not be identified to species. The percent occurrence of plants (all substrate species combined) with overwintered colonies increased with depth in 2007 (arcsine-square root $y=-0.195+$ $0.095 x_{i}$ adjusted $\left.R^{2}=0.40, p=0.002\right)$, but not in 2005 (adjusted $\mathrm{R}^{2}=0.063, \mathrm{p}=0.092$ )

larvae of $M$. membranacea settle preferentially on flat surfaces far from discontinuities (Walters \& Wethey 1991). It is also very likely that growth (as measured by linear extension of the colony, Saunders \& Metaxas 2009 ) is lower on A. clathratum than on the other 2 kelp species. Because of the perforated blades, colonies have a complex pattern of growth through and around each hole. Thus, a combination of lower recruitment (indicated by lower number of colonies) and reduced growth or partial colony survival (indicated by smaller maximum colony sizes), resulted in lower coverage of the bryozoan on A. clathratum than on Saccharina longicruris.
Infestation by Membranipora membranacea and the response of the algal substrate to an outbreak varies among species. In fall 2006, an outbreak of M. membranacea resulted in significant defoliation of Nova Scotian kelp beds between mid-October and midNovember (indicated by a reduction in benthic canopy cover of Saccharina longicruris, Saunders \& Metaxas 2008). The loss during this 1 mo period was also manifested as a loss of individual plants between June 2005 and June 2007. However, this decrease in the number of plants was not as evident in the other numerically abundant kelp species. The abundance of A. clathratum decreased only at the deepest locations at both sites, and that of Laminaria digitata did not change at Paddy's Head, and in fact increased at the shallowest location at Lodge. The loss of Agarum clathratum at $12 \mathrm{~m}$ is puzzling, since we never documented high bryozoan cover on that species at that depth; it is possible that a peak in bryozoan cover occurred between sampling dates in June and November 2006, and the bryozoan was lost concurrently with the kelp blades by November 2006.

We suggest that successive cycles of bryozoan outbreaks could be resulting in a shift in the algal community structure, with species more resistant to colonization by Membranipora membranacea (Agarum clathratum) or breakage (Laminaria digitata) potentially replacing those less resistant (e.g. Saccharina longicruris). Indeed, Harris \& Tyrrell (2001) qualitatively described an increase in A. clathratum in shallower water during the 1990s in the Gulf of Maine. However, long-term studies of the kelp assemblages spanning the period of introduction and establishment of $M$. membranacea would be necessary to examine this process.

We clearly demonstrate that in Nova Scotia, colonies of Membranipora membranacea can overwinter on a number of kelp substrates, and these colonies could provide the larvae for the first settlement in May or June (Saunders \& Metaxas 2007). We observed higher incidence of overwintered colonies on Laminaria digitata and Agarum clathratum than on Saccharina longicruris, similar to results from the Gulf of Maine (Harris \& Jones 2005). In 1 year, the incidence of overwintered colonies on kelps increased with depth, and depending on location, overwintered colonies were observed on up to $85 \%$ of bladeless stipes in the kelp beds. The presence of such colonies suggests that $M$. membranacea populations can be maintained in the absence of an intact kelp canopy for the duration of persistence of these stipes.

Acknowledgements. We thank J. Lindley, A. Pinder, D. Lyons, J.-S. Lauzon-Guay, D. Taylor, B. Rowland, J. Sperl, A. Schmidt, L. Sauchyn, S. Watanabe, O. D'Amours, A. Comeau, 
M. Kluge, and N. Kamenos for assistance in the field, and D. Knip, M. Beck, and J. Arbour for assistance in the laboratory. The research was supported by Natural Sciences and Engineering Research Council of Canada (NSERC) Discovery grants to A.M. and R. E. Scheibling, and an NSERC Canada Graduate Scholarship, Killam Predoctoral Fellowship, Dalhousie University President's Award, and Faculty of Graduate Studies Fellowship to M.I.S.

\section{LITERATURE CITED}

Berman J, Harris L, Lambert W, Buttrick M, Dufresne M (1992) Recent invasions of the Gulf of Maine: three contrasting ecological histories. Conserv Biol 6:435-441

Bernstein BB, Jung N (1979) Selective pressures and coevolution in a kelp canopy community in southern California. Ecol Monogr 49:335-355

Chapman AS, Scheibling RE, Chapman ARO (2002) Species introductions and changes in the marine vegetation of Atlantic Canada. In: Claudi R, Nantel P, Muckle-Jeffs E (eds) Alien invaders in Canada's waters, wetlands, and forests. Natural Resources Canada, Canadian Forest Service, Science Branch, Ottawa, p 133-148

> Gerard VA, Mann KH (1979) Growth and production of Laminaria longicruris (Phaeophyta) populations exposed to different intensities of water movement. J Phycol 15:33-41

$>$ Harder DL, Hurd CL, Speck T (2006) Comparison of mechanical properties of four large, wave-exposed seaweeds. Am J Bot 93:1426-1432

> Harris LG, Jones AC (2005) Temperature, herbivory and epibiont acquisition as factors controlling the distribution and ecological role of an invasive seaweed. Biol Invasions 7:913-924

Harris LG, Tyrrell MC (2001) Changing community states in the Gulf of Maine: synergism between invaders, overfishing and climate change. Biol Invasions 3:9-21

Hurd CL, Durante KM, Chia FS, Harrison PJ (1994) Effect of bryozoan colonization on inorganic nitrogen acquisition by the kelps Agarum fimbriatum and Macrocystis integrifolia. Mar Biol 121:167-173

Jennings JG, Steinberg PD (1997) Phlorotannins versus other factors affecting epiphyte abundance on the kelp Ecklonia radiata. Oecologia 109:461-473

Johnson CR, Mann KH (1986) The importance of plant defense abilities to the structure of subtidal seaweed communities: The kelp Laminaria longicruris de la Pylaie survives grazing by the snail Lacuna vincta (Montagu) at high population densities. J Exp Mar Biol Ecol 97:231-267

Lambert WJ, Levin PS, Berman J (1992) Changes in the structure of a New England (USA) kelp bed: the effects of an introduced species? Mar Ecol Prog Ser 88:303-307

Lane CE, Mayes C, Druehl LD, Saunders GW (2006) A multigene molecular investigation of the kelp (Laminariales, Phaeophyceae) supports substantial taxonomic reorganization. J Phycol 42:493-512

Larson BR, Vadas RL, Keser M (1980) Feeding and nutritional ecology of the sea urchin Strongylocentrotus drobachiensis in Maine, USA. Mar Biol 59:49-62

Levin PS, Coyer JA, Petrik R, Good TP (2002) Communitywide effects of nonindigenous species on temperate rocky reefs. Ecology 83:3182-3193

> Lyons DA, Scheibling RE (2007) Effect of dietary history and algal traits on feeding rate and food preference in the green sea urchin Strongylocentrotus droebachiensis. J Exp Mar Biol Ecol 349:194-204

Editorial responsibility: Riccardo Cattaneo-Vietti, Genova, Italy
Makarov V, Makarov M, Schoschina E (1999) Seasonal dynamics of growth in the Barents Sea seaweeds: endogenous and exogenous regulation. Bot Mar 42:43-49

> Mann KH (1973) Seaweeds: their productivity and strategy for growth. Science 182:975-981

> Nylund GM, Pavia H (2005) Chemical versus mechanical inhibition of fouling in the red alga Dilsea carnosa. Mar Ecol Prog Ser 299:111-121

Ragan MA, Glombitza KW (1986) Phlorotannins, brown algal polyphenols. Prog Phycol Res 4:129-241

Ryland JS (1959) Experiments on the selection of algal substrates by polyzoan larvae. J Exp Biol 36:613-631

Saunders M, Metaxas A (2007) Temperature explains settlement patterns of the introduced bryozoan Membranipora membranacea in Nova Scotia, Canada. Mar Ecol Prog Ser 344:95-106

Saunders M, Metaxas A (2008) High recruitment of the introduced bryozoan Membranipora membranacea is associated with kelp bed defoliation in Nova Scotia, Canada. Mar Ecol Prog Ser 369:139-151

Saunders MI, Metaxas A (2009) Effects of temperature, size, and food on the growth of Membranipora membranacea in laboratory and field studies. Mar Biol 156:2267-2276

Schaffelke B, Lüning K (1994) A circannual rhythm controls seasonal growth in the kelps Laminaria hyperborea and L. digitata from Helgoland (North Sea). Eur J Phycol 29: 49-56

Scheibling RE, Gagnon P (2006) Competitive interactions between the invasive green alga Codium fragile ssp. tomentosoides and native canopy-forming seaweeds in Nova Scotia (Canada). Mar Ecol Prog Ser 325:1-14

Scheibling RE, Gagnon P (2009) Temperature-mediated outbreak dynamics of the invasive bryozoan Membranipora membranacea in Nova Scotian kelp beds. Mar Ecol Prog Ser 390:1-13

> Scheibling RE, Hennigar AW, Balch T (1999) Destructive grazing, epiphytism, and disease: the dynamics of sea urchin-kelp interactions in Nova Scotia. Can J Fish Aquat Sci 56:2300-2314

Schmidt AL, Scheibling RE (2007) Effects of native and invasive macroalgal canopies on composition and abundance of mobile benthic macrofauna and turf-forming algae. J Exp Mar Biol Ecol 341:110-130

Schwaninger HR (1999) Population structure of the widely dispersing marine bryozoan Membranipora membranacea (Cheilostomata): implications for population history, biogeography, and taxonomy. Mar Biol 135:411-423

Schwaninger HR (2008) Global mitochondrial DNA phylogeography and biogeographic history of the antitropically and longitudinally disjunct marine bryozoan Membranipora membranacea L. (Cheilostomata): another cryptic marine sibling species complex? Mol Phylogenet Evol 49: 893-908

Seed R, O'Connor RJ (1981) Community organization in marine algal epifaunas. Annu Rev Ecol Syst 12:49-74

Stricker SA (1989) Settlement and metamorphosis of the marine bryozoan Membranipora membranacea. Bull Mar Sci 45:387-405

Van Alstyne KL, McCarthy JJ, Hustead CL, Kearns LJ (1999) Phlorotannin allocation among tissues of northeastern Pacific kelps and rockweeds. J Phycol 35:483-492

Wahl M (2009) Epibiosis: ecology, effects and defences. In: Wahl M (ed) Marine hard bottom communities. Ecological studies series, Vol 206. Springer, Berlin, p 61-72

Walters LJ, Wethey DS (1991) Settlement, refuges, and adult body form in colonial marine invertebrates: a field experiment. Biol Bull (Woods Hole) 180:112-118

Submitted: July 21, 2009; Accepted: November 4, 2009

Proofs received from author(s): December 23, 2009 